\title{
Diurnal and Seasonal Patterns of Methane Emissions from a Dairy Operation in North China Plain
}

\author{
Zhiling Gao, ${ }^{1}$ Huijun Yuan, ${ }^{1,2}$ Wenqi Ma, ${ }^{1}$ Jianguo Li, ${ }^{3}$ Xuejun Liu, ${ }^{4}$ \\ and Raymond L. Desjardins ${ }^{5}$ \\ ${ }^{1}$ College of Resources and Environmental Sciences, Agricultural University of Hebei, Baoding 071000, China \\ ${ }^{2}$ Baoding Municipal Environmental Monitoring Station, Baoding 071000, China \\ ${ }^{3}$ College of Animal Science and Technology, Agricultural University of Hebei, Baoding 071000, China \\ ${ }^{4}$ College of Resources and Environmental Sciences, China Agricultural University, Beijng 100193, China \\ ${ }^{5}$ Research Branch, Agriculture and Agri-Food Canada, Ottawa, ON, Canada K1A 0C6
}

Correspondence should be addressed to Zhiling Gao, zhilinggao@hotmail.com

Received 22 August 2011; Accepted 10 November 2011

Academic Editor: Hann-Ming Henry Juang

Copyright (c) 2011 Zhiling Gao et al. This is an open access article distributed under the Creative Commons Attribution License, which permits unrestricted use, distribution, and reproduction in any medium, provided the original work is properly cited.

In China, dairy cattle managed in collective feedlots contribute about $30 \%$ of the milk production and are believed to be an important contributor to national methane emissions. Methane emissions from a collective dairy feedlot in North China Plain (NCP) were measured during the winter, spring, summer, and fall seasons with open-path lasers in combination with an inverse dispersion technique. Methane emissions from the selected dairy feedlot were characterized by an apparent diurnal pattern with three peaks corresponding to the schedule of feeding activities. On a per capita basis, daily methane emission rates of these four seasons were $0.28,0.32,0.33$, and $0.30 \mathrm{~kg} \mathrm{head}^{-1} \mathrm{~d}^{-1}$, respectively. In summary, annual methane emission rate was $112.4 \mathrm{~kg} \mathrm{head}^{-1} \mathrm{yr}^{-1}$ associated with methane emission intensity of $32.65 \mathrm{~L} \mathrm{CH}_{4} \mathrm{~L}^{-1}$ of milk and potential methane conversion factor $\mathrm{Y}_{\mathrm{m}}$ of $6.66 \%$ of gross energy intake for mature dairy cows in North China Plain.

\section{Introduction}

The dairy cow population in China has increased from 40,000 animals to 13.25 million animals during the period of 1949-2006. Dairy production has become one of the most profitable and increasing industries in the agriculture sector in China. For example, in 2008, the GDP originated from Chinese dairy industry was $¥ 101.5$ billion, which accounted for about $10 \%$ of the total animal production and about $3.0 \%$ of total agricultural production [1].

Considerable efforts have been made to estimate enteric methane emissions from dairy cows in China in order to improve the accuracy of national methane inventory [2-4]. These inventories are mainly based on the Intergovernmental Panel on Climate Change (IPCC) methodology. However, many studies have demonstrated that methane emissions from ruminants are strongly influenced by factors such as feeding activity, composition of feedstuffs, and use of additives, which are not included in the IPCC methodology.
In China, management practices are frequently different from one dairy facility to another; hence, large uncertainties in the inventory estimates are anticipated.

Dairy cattle in China are being managed in different types of dairy facilities. Based on the number of animals, these facilities are either classified as intensive, collective, or household level operations [5]. As reported by $\mathrm{Ma}$ et al. [6], about $45 \%, 29.3 \%$, and $25.9 \%$ of the Chinese dairy cow population is held in household, collective, and intensive dairy facilities, respectively, and the collective dairy feedlot has been considered a transition phase that links the transformation from household to intensive level. For example, the management of manure in collective systems is similar with the intensive facility but the feed composition and feeding activities might differ from pen to pen because it is mainly determined by separate owners. As a result, the methane emission factors from dairy cows in collective facilities should be different from those in household or intensive facilities due to different feeds management. 
Therefore, measurements are required to quantify these emission factors in order to improve the accuracy of present methane inventories as well as to evaluate the effectiveness of mitigation strategies for reducing methane emission from the dairy industry.

A previous measurement carried out in North China has been published by Gao et al. [7]. However, more actual measurement results are required because, firstly, in that study, methane emissions from dairy feedlot were quantified only in fall and winter seasons; secondly, herd composition in that dairy operation only represents one of management practices in North China. Therefore, to fully characterize the methane emissions at whole farm scale during a full year and enhance our understanding on the impact of herd composition on methane emissions, in this study, we used similar measurement techniques and strategies as Gao et al. [7] to quantify methane emissions from a collective dairy feedlot in Baoding, North China. The objectives of this study were to: (1) further confirm the temporal pattern of methane emissions, (2) calculate annual emission rates, and (3) estimate the potential methane conversion factor $Y_{m}$ for dairy cattle managed in collective dairy operation in North China Plain.

\section{Material and Methods}

2.1. Experimental Site. A collective dairy feedlot in Baoding city in North China Plain was selected for characterizing and quantifying methane emissions at whole farm scale. Four field campaigns during winter (Dec. 1 to 31 in 2009), spring (Mar. 17 to Apr. 11 in 2010), summer (Jun. 13 to Jul. 17 in 2010), and fall (Oct. 29 to Nov. 16 in 2010) seasons were carried out respectively. Around the dairy operation, there were no other significant methane sources within 1 kilometer of the measurement site.

2.1.1. Description of Feedlot. Within this dairy operation, all the dairy cattle including milking cows, dry cow, heifers, and calves were managed in 8 large pens as shown in Figure 1. The total area of the feedlot was 4.91 ha and the total capacity was about 1800 heads. The dairy population of this operation during the four seasons varied from 1204 to 1519 with an average of 1345 heads. The herd distribution within these eight pens during the summer is given in Table 1 . The average density ranged from 29.2 to $39.4 \mathrm{~m}^{2}$ head ${ }^{-1}$. Effort was made to separate calves less than 3 months from mature cows, that is, calves were usually fenced in a mini pen (approximately $3 * 3 \mathrm{~m}^{2}$ ) close to the shelter within a regular pen at the corner.

In addition, there were shelters for feeds storage between pens 1 and 2, 3 and 4, 5 and 6, and 7 and 8 (Figure 1). Alleyways (approximately $1.5-3.0 \mathrm{~m}$ wide) for moving milking cows from dairy pens to the milking hall were between pens 2 and 3, 4 and 5, and 6 and 7. The feedlot floor was paved with bricks. Manure in the feedlot was removed periodically and collected for either mushroom or vegetable cultivation. Of the dairy population, about $54 \%$ of herd were lactating cows, the rest were dry cows and heifers over one year age and calves (6-12 month) (Table 2).

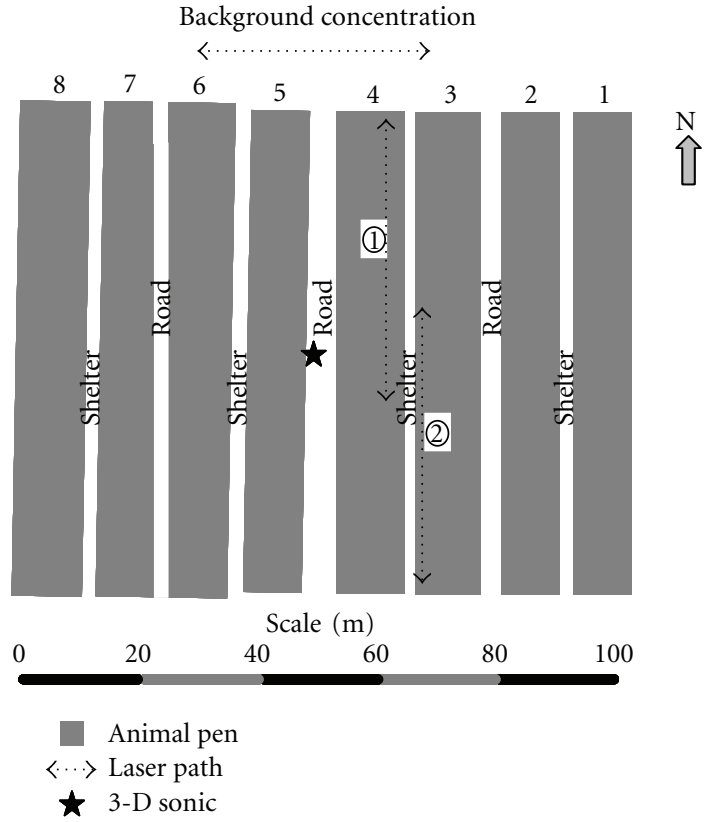

FIgure 1: Overview of the feedlot and an illustration of the locations of instruments. Laser-path labeled (1) was used for the winter period and the path labeled (2) was used for the spring, summer, and fall periods.

TABLE 1: Average animal population and density for each pen during the summer period.

\begin{tabular}{lcc}
\hline Pen ID & Total population (head) & Density $\left(\mathrm{m}^{2}\right.$ head $\left.^{-1}\right)$ \\
\hline 1 & 210 & 29.2 \\
2 & 188 & 32.7 \\
3 & 187 & 32.8 \\
4 & 177 & 34.7 \\
5 & 156 & 39.4 \\
6 & 173 & 35.5 \\
7 & 180 & 34.1 \\
8 & 169 & 36.3 \\
\hline
\end{tabular}

2.1.2. Dairy Operation. Dairy cattle were fed three times a day at 4:30 am, 11:30 am, and 4:30 pm, respectively. Each feeding period lasted about one hour. As shown in Table 2, the ration mainly included fermented corn silage and concentrate diet. Only a few farmers fed corn grain and soybean meal at this feedlot. Lactating cows were milked twice a day between 4:30-6:30 am and 4:30-6:30 pm. The milk production per milking cow was about $14.5 \pm 1.7 \mathrm{~kg} \mathrm{head}^{-1} \mathrm{~d}^{-1}$ with the fat and protein contents of $3.4 \%$ and $3.0 \%$, respectively. The fat and protein corrected (FPCM) milk production was $13.2 \pm 1.55 \mathrm{~kg} \mathrm{head}^{-1} \mathrm{~d}^{-1}[8]$.

2.2. Methane Measurement. An open-path laser system (GasFinder MC, Boreal Laser Inc. Edmonton, Canada) was used to measure methane concentrations. It works in the near Infrared $(1653 \mathrm{~nm})$ and consists of a laser transmitter head and a reflector. The laser beam is transmitted from 
TABLE 2: Herd structure and feed composition during the four seasons.

\begin{tabular}{lcccc}
\hline Items & Heads & Corn silage $\left(\mathrm{kg} \mathrm{head}^{-1} \mathrm{~d}^{-1}\right)$ & Concentrates $\left(\mathrm{kg} \mathrm{head}^{-1} \mathrm{~d}^{-1}\right)$ & Total dry matter intake $\left(\mathrm{kg} \mathrm{head}^{-1} \mathrm{~d}^{-1}\right)$ \\
\hline Lactating cows & 722 & 10.48 & 9.25 & 19.73 \\
Nonlactating cows & 216 & 9.55 & 2.49 & 12.04 \\
Heifer (12-24 months) & 238 & 8.68 & 4.87 & 13.55 \\
Calves (3-12 months) & 103 & 3.71 & 2.36 & 6.07 \\
Calves (<3 months) & 66 & & & \\
\hline
\end{tabular}

the control unit to the transmitter head via a fiber-optic cable and then directed to a retroreflector through the air. In-field calibration showed that the actual detection sensitivity of the open-path laser system was $2-3 \mathrm{ppm} * \mathrm{~m}$ (equivalent to about $0.03 \mathrm{ppm}_{\mathrm{v}}$ with a path length of $100 \mathrm{~m}$ ) and also showed that the concentration measurements were underestimated; thus, a correction factor of 1.06 obtained from this in-field test was used for all the measurements. Laser sensors and reflectors were installed on two masts within the feedlot. The laser path length was $123 \mathrm{~m}$ for path (1) and 124 for path (2). The heights of both laserpaths were $2.4 \mathrm{~m}$ (Figure 1). Methane background concentrations were measured at north side of the feedlot when the wind was northerly during each measurement period. Methane concentrations were recorded every second and the 15-min averages were stored.

2.3. Micrometeorological Measurements. A Gill 3-D sonic anemometer (Gill Instrument Ltd. Lymington, UK), installed on a mast near the center of the feedlot at a height of $6 \mathrm{~m}$ above the ground surface, was used to characterize the micrometeorological conditions of the feedlot (Figure 1). The measurement height was determined with the assumption that the characteristics of the internal boundary layer within the feedlot area can be measured when the ratio of the sonic sensor height to fetch ratio is less than 0.1. In our case, this ratio varied from 0.04 to 0.05 with wind directions. During all measurement periods, wind velocities and temperature were measured at a frequency of $10 \mathrm{~Hz}$. Raw wind parameters were sampled using EdiSol and calculated for 15-min intervals using EdiRe software package both developed by University of Edinburgh. These data are utilized to compute the feedlot wind parameters used in the bLS dispersion technique such as $u *$, Obukhov stability length $(L)$, roughness length $\left(z_{0}\right)$, wind direction $(\beta)$, and standard deviations of the velocity components $\left(\sigma_{u, v, w}\right)$.

2.4. Calculation of Methane Emission Rates. The software WindTrax (http://www.thunderbeachscientific.com/) was used to calculate methane emissions $\left(\mathrm{Q}_{\mathrm{bLS}}\right)$. This software package is based on the bLS dispersion model described by Flesch et al. $[9,10]$. The model assumes a diabatic logarithmic mean wind profile and traditional MoninObukhov Similarity Theory (MOST) relationships for the turbulent statistics [10]. By assuming an ideal surface layer associated with a stationary atmosphere, the wind statistics can be determined with the sonic-derived parameters $(U$, $\beta, z_{0}, L$ and $\left.\sigma_{u, v, w}\right)$. This technique has been successfully used to quantify emissions from animal facilities in many publications because it is capable of mimicking numerical trajectories efficiently and provide accurate emission estimates.

In addition, the data filtering criteria for the 15-min average micrometeorological parameters suggested by [10, 11] were used in order to satisfy the assumptions in Wind Trax. Thus, periods with parameters that did not fulfill the following requirements were rejected:

(1) $u *>0.15 \mathrm{~m} \mathrm{~s}^{-1}$

(2) $|L|>10 \mathrm{~m}$ (eliminate extremely stable or unstable micrometeorological cases),

(3) $z_{0}<0.15 \mathrm{~m}$ (in this feedlot environment, $z_{0}$ greater than $0.15 \mathrm{~m}$ was associated with erroneous wind profile),

(4) the percentage of touchdown covered feedlot area of total feedlot area was greater than $20 \%$. This value might be varied with size of emission sources from $5 \%[11]$ to $40-50 \%[12,13]$.

2.5. Gross Energy Intake. During each measurement period, the dry matter intake for lactating cows and nonlactating cows and heifers was measured (Table 2). For each category, 20 animals were selected and the fresh feeds including silage and concentrates were weighted on farm and the respective samples were taken into lab for analysis. The average feed intakes of 20 animals for each category were used for the calculation of energy intake and methane conversion factor $\mathrm{Y}_{\mathrm{m}}$.

\section{Results and Discussion}

3.1. Variations in the Methane Concentration. Measurements outside the feedlot showed that methane background concentration varied from 1.82 to $1.91 \mathrm{ppm}_{\mathrm{v}}$. Hourly mean methane concentration within the feedlot during each measuring periods is shown in Figure 2. These varied from approximately $2.05 \mathrm{ppm}_{\mathrm{v}}$ to about $7.34 \mathrm{ppm}_{\mathrm{v}}$. Thus, is the minimal methane concentration rise over the background was about 0.1-0.2 $\mathrm{ppm}_{\mathrm{v}}$, which was substantially larger than the resolution of open-path laser system of $0.03 \mathrm{ppm}_{\mathrm{v}}$.

3.2. Diurnal Pattern of Methane Emissions. After applying the data filtering criteria given in Section 2.4, emission estimates were calculated using WindTrax package. During the four measurement periods, the wind direction varied from 0 to 359 degrees, indicating that emissions from the entire feedlot were observed. In order to obtain an unbiased 


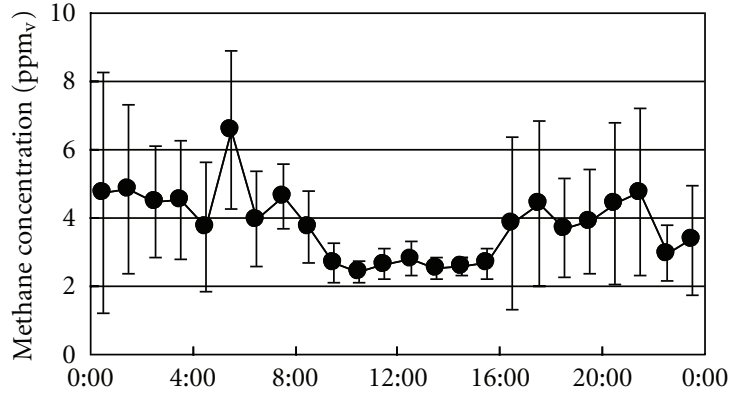

(a)

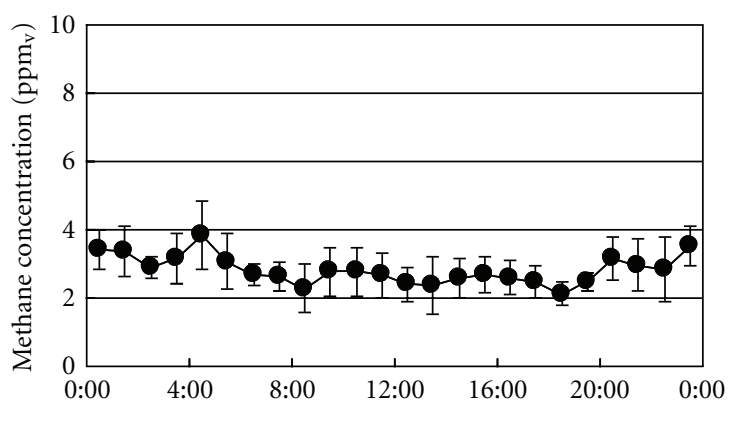

(c)

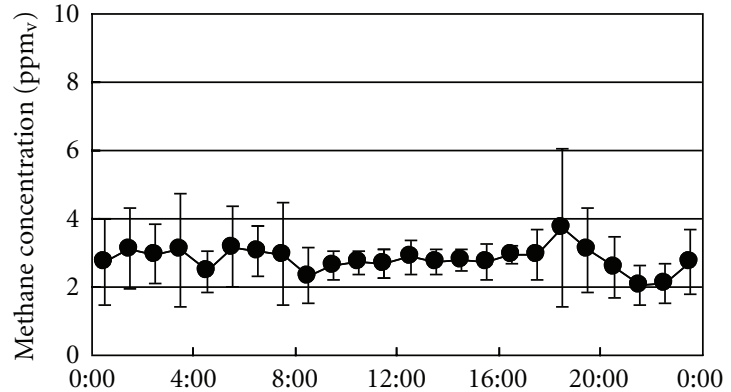

(b)

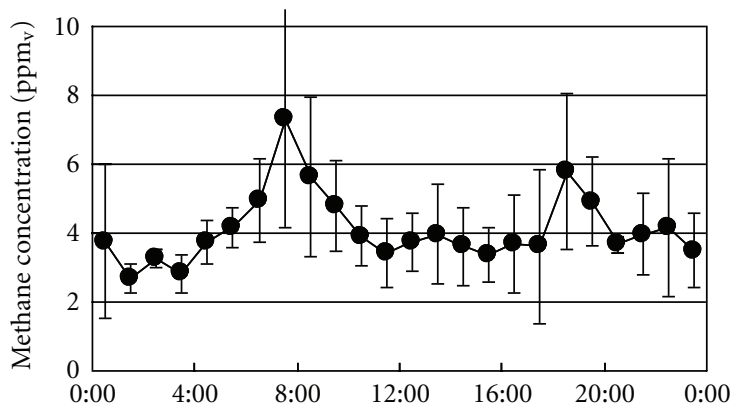

(d)

FIGURE 2: Hourly mean methane concentrations at $2.4 \mathrm{~m}$ during winter (a), spring (b), summer (c), and fall (d) measurement periods. Bars indicate the range of concentration within \pm standard deviation.

emission estimate for each measurement period, that is, not overweighted toward a particular time of day, hourly average emission rates were calculated using an ensemble average of usable 15-min estimates during each hour across each seasonal measurement period $[12,14,15]$. For all cases, at least 11 estimates were available for each hour.

By using the above strategy, hourly methane emission rates on per capita basis for winter, spring, summer, and fall seasons are presented in Figure 3. Hourly emissions per capita varied from 6.8 to $23.1 \mathrm{~g} \mathrm{hr}^{-1}$ (winter), 7.0 to $21.6 \mathrm{~g} \mathrm{hr}^{-1}$ (spring), 9.9 to $22.6 \mathrm{~g} \mathrm{hr}^{-1}$ (summer), and 2.1 to $30.1 \mathrm{~g} \mathrm{hr}^{-1}$ (fall), respectively. For measurement seasons of winter and spring, three methane emission peaks during a day were observed, starting at approximately 5:00 am, 11:30 am and 4:00 pm, peaking at 7:00 am, 12:00 am, and 6:00 pm, and lasting about $2-5$ fours. However, this pattern in summer and fall seasons was not as clear as winter and summer seasons. These peaks appear to correspond to the feeding activities $[11,16]$. Similar patterns have been previously reported by Kinsman et al. [17] and Gao et al. [7]. In addition, measurements on a beef feedlot also showed a similar pattern related to the feeding time [14].

3.3. Seasonal Pattern of Methane Emissions. When calculating the methane emission rate on an animal basis, the contribution by calves less than three months was neglected $[18,19]$. Based on this procedure, the emissions rate on a per animal basis were $0.28,0.32,0.33$, and $0.30 \mathrm{kghead}^{-1} \mathrm{~d}^{-1}$, respectively, associated with an error of $0.04,0.05,0.05$, and $0.04 \mathrm{~kg} \mathrm{head}^{-1} \mathrm{~d}^{-1}$ (this error is estimated with an $15 \%$ error of the bLS model suggested by Harper et al. [11]) during winter, spring, summer, and fall. Through this study, differences of about $21 \%$ were observed between summer and winter. This apparent difference might be partly attributed to the relatively lower methane emissions from manure within the feedlot due to the low temperature during the winter period $[20,21]$. Methane emission rates during summer and spring are very similar yet considerably greater than during winter time.

In order to understand the relationship between methane emission rates and temperatures, further analysis was conducted. Hourly average air temperatures for each hour during each measurement season were calculated, where the mean daily air temperatures during winter, spring, summer, and fall seasons were $-3.2,9.5,27.3$, and $8.3^{\circ} \mathrm{C}$, respectively. The average daily methane emission rates and the corresponding air temperatures are plotted in Figure 4. It can be seen that methane emission rate appeared to increase with air temperature, which to some extent confirms the temperature impact on methane emission reported by [22] and Amon et al. [23]. But such temperature-derived influence is still debatable due to an error of approximately $15 \%$ with the inverse dispersion technique used in this study $[12,24]$, and more measurements are required to examine this issue.

3.4. Annual Methane Emission Rates from this Dairy Operation. Annual methane emission on a per animal basis from this collective dairy feedlot was calculated by averaging emission rates of four measurements. Given an error of $15 \%$ of the inverse dispersion technique, the calculated methane emission rate of $112.4 \pm 16.9 \mathrm{~kg} \mathrm{animal}^{-1} \mathrm{yr}^{-1}$ includes the 


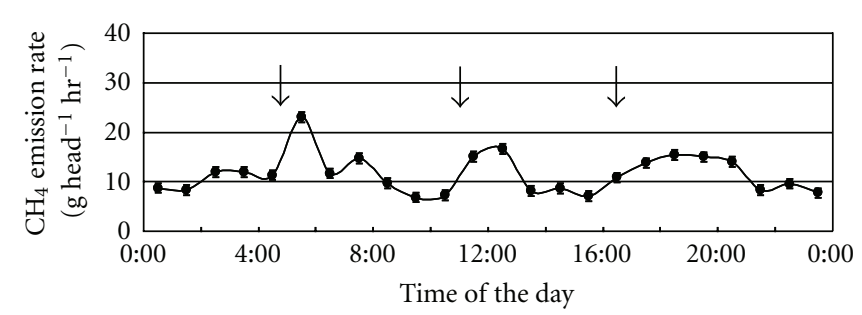

(a)

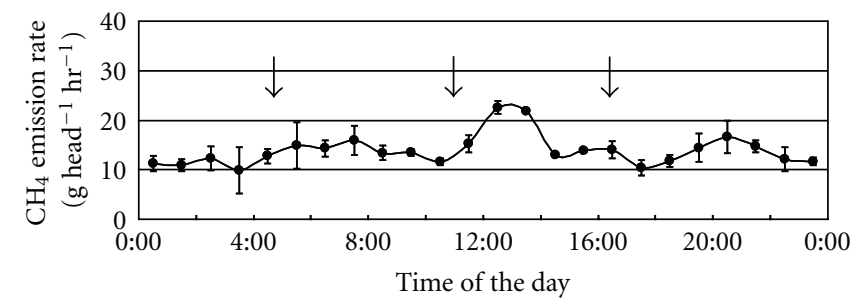

(c)

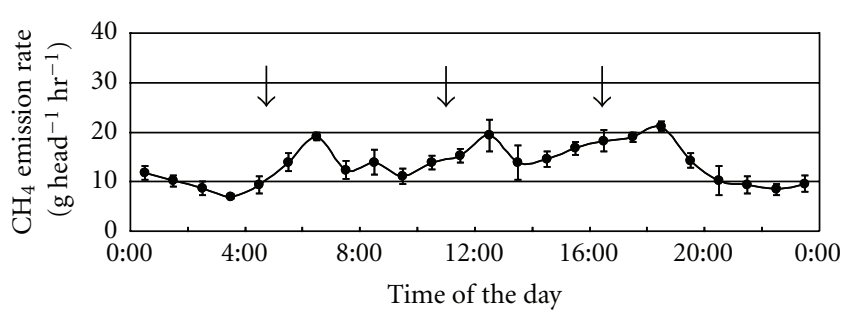

(b)

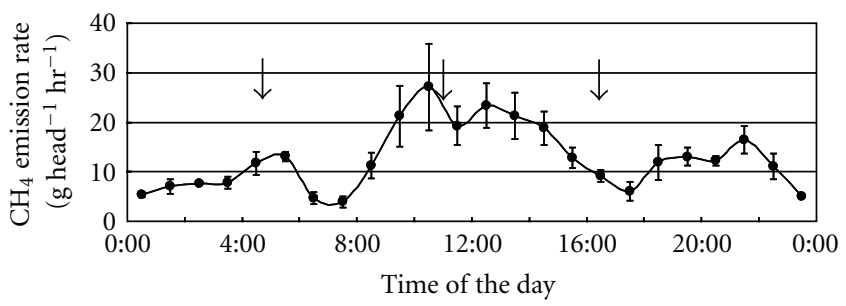

(d)

Figure 3: Diurnal patterns of methane emissions over the feedlot during winter (a), spring (b), summer (c), and fall (d) seasons. Bars indicate the uncertainty of hourly averaged methane emission rates and arrows indicate the timing of feeding activities on this feedlot.

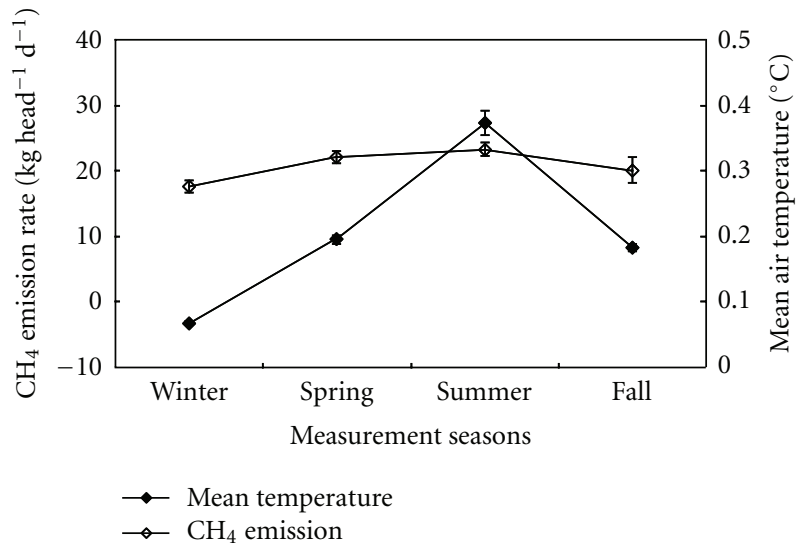

Figure 4: Daily methane emission rates and average temperature during winter, spring, summer, and fall seasons.

enteric emissions from lactating, nonlactating cows, heifers, and calves (3-12 months) and emissions from manure within the feedlot. This value is very similar in comparison with a previous study by Gao et al. [7] also carried out in Baoding. If we assume the methane emission rate from manure was about $10 \mathrm{~kg} \mathrm{animal}^{-1} \mathrm{yr}^{-1}$ [21], further calculations can be made to obtain the ensemble average enteric emission rate of dairy cattle including lactating, nonlactating cows, heifers, and calves (3-12 months), which was $102.4 \mathrm{~kg} \mathrm{CH}_{4}$ animal ${ }^{-1} \mathrm{yr}^{-1}$.

Many studies have quantified methane emissions from dairy cattle using various methods. For example, McGinn et al. [25] who used the same measurement technique for a whole herd with lactating and nonlactating cows, heifers, and less than one year calves obtained slightly greater emissions. From a global view, a relatively wider range of emission factors was obtained for lactating cows: $142-146 \mathrm{~kg} \mathrm{CH}_{4}$ animal ${ }^{-1} \mathrm{yr}^{-1}$ by Kinsman et al. [17],
$146 \mathrm{~kg}$ animal ${ }^{-1} \mathrm{yr}^{-1}$ by Laubach and Kelliher [26], and 118$121 \mathrm{~kg}$ animal ${ }^{-1} \mathrm{yr}^{-1}$ by Grainger et al. [27]. It appears that this emission factor is close to the lower end of the range presented in the literature, which may be due to the relatively low methane emission rates of heifers. In order to better compare the emission rate of mature cows (i.e., lactating and nonlactating cows) in this study to literatures, further calculations for only lactating and nonlactating cows were made with the assumption that the methane emission rates of heifers and calves (3-12 months) were $40 \mathrm{~kg} \mathrm{animal}^{-1} \mathrm{yr}^{-1}$ [28] and $62 \mathrm{~kg} \mathrm{animal}^{-1} \mathrm{yr}^{-1}$ [29], respectively. By considering the herd structure showed in Table 2, ensemble annual methane emission rate of $132.5 \pm 19.9 \mathrm{~kg} \mathrm{animal}^{-1} \mathrm{yr}^{-1}$ for mature cattle of lactating and nonlactating cows was obtained, which falls into the middle emission rates range in the literature.

Methane emission intensity based on milk production basis was calculated using the obtained methane emission rate and milk production on the basis of milk fat content of $4.0 \%$ and protein content of $3.3 \%$ [8]. It showed that, in our study, a methane emission intensity of $0.023 \mathrm{~kg} \pm 0.003 \mathrm{CH}_{4} \mathrm{~kg}^{-1} \mathrm{~d}^{-1}$ of milk (i.e., $32.65 \pm$ $4.78 \mathrm{~L} \mathrm{CH}_{4} / \mathrm{L}$ of milk) was obtained. This value is similar to that of $32.2 \mathrm{~L} \mathrm{CH}_{4} / \mathrm{L}$ of milk in a previous study by; Gao et al. [7] but higher than other literatures such as $24.9 \mathrm{~L} \mathrm{CH}_{4} \mathrm{~kg}^{-1}$ of milk by Vergè et al. [30], 21.4 $\mathrm{L} \mathrm{CH}_{4} \mathrm{~kg}^{-1}$ of milk by Sauer et al. [31] and 20.6 $\mathrm{L} \mathrm{CH}_{4} \mathrm{~kg}^{-1}$ of milk by Kinsman et al. [17], which appears to confirm the relatively low milk productivity in China [7].

3.5. Calculation of Methane Conversion Factor $\left(Y_{m}\right)$. It has been reported in the literature that methane conversion factors $\left(\mathrm{Y}_{\mathrm{m}}\right)$ for ruminant livestock ranged from $4.0 \%$ to $10 \%$ [32]. In order to estimate $\mathrm{Y}_{\mathrm{m}}$ for mature cows in our study, several assumptions were made based on a previous study [7]. As described above, the methane emission rate of 
enteric fermentation for our mature dairy cattle was estimated at $132.5 \pm 19.9 \mathrm{~kg}$ animal ${ }^{-1} \mathrm{yr}^{-1}$. For the calculation of total gross energy intake, daily dry matter intakes of corn silage and concentrate consumed by mature dairy cows were calculated by weighting the animal numbers and daily dry matter intakes of each animal category; digestible energy corresponding to each component of feeds was obtained from $\mathrm{Li}$ [33] and Wang [34], and the estimated value of gross energy intake (GE) for mature dairy cows was 303.28 MJ animal $^{-1} \mathrm{~d}^{-1}$, where $36 \%$ and $64 \%$ of the total were provided by corn silage and concentrate, respectively. Furthermore, lactating and nonlactating cows were assumed to have the same $\mathrm{Y}_{\mathrm{m}}$. With all the assumptions above, by using the IPCC [21] Tier II methodology, the actual $Y_{m}$ for mature dairy cows in this facility was calculated to be $6.66 \%$, which agrees well with the IPCC suggested value of $6.5 \%$ for dairy cows. However, this $\mathrm{Y}_{\mathrm{m}}$ value is smaller than the value of $7.3 \%$ in a previous study by Gao et al. [7] and the results of $7.3 \%$ and 7.1\%; respectively, by Johnson et al. [35] and Boadi and Wittenberg [36] also for forage-fed mature cows. But it is much higher than the value of $2-3 \%$ for high concentrate feed or the value of $4-5 \%$ for highly digestible fiber feed $[37,38]$.

\section{Conclusions}

In this paper, a combination of an inverse dispersion technique and open-path laser was used to quantify diurnal and seasonal patterns of methane emissions from a collective dairy feedlot in North China in winter, spring, summer, and fall. As expected, daily methane emissions were characterized with a diurnal pattern with peaks corresponding to the feeding schedule. We also found that the ensemble average methane emission rates during winter, spring, summer and fall were $0.28,0.32,0.33$, and $0.30 \mathrm{~kg} \mathrm{head}^{-1} \mathrm{~d}^{-1}$. Overall, annual methane emission rate for dairy cattle in this collective dairy feedlot was $112.4 \pm 16.9 \mathrm{~kg} \mathrm{head}^{-1} \mathrm{yr}^{-1}$ associated with methane emission intensity of $32.65 \pm 4.78 \mathrm{~L} \mathrm{CH}_{4} \mathrm{~L}^{-1}$ of milk and methane conversion factor of $6.66 \%$ of gross energy intake for mature dairy cows.

\section{Acknowledgments}

Funding support was from National Natural Science Foundation of China (NSFC: 41075105), BMBF (KFZ: 0330847AB) and Ministry of Agriculture, China (MOA: 201103003). The authors are also thankful for the loan of open-path laser system from Agriculture and Agri-Food Canada (AAFC) and for the valuable suggestions and comments by anonymous reviewers.

\section{References}

[1] L. Zan, X. Fu, and S. Li, "Countermeasures, present conditions, problems and development trends of the Chinese milk industry," Chinese Agricultural Science Bulletin, vol. 21, no. 8, pp. 19-22, 2005.

[2] ADB, "Asian Least-Cost greenhouse gas abatement strategiesPeople's Republic of China, 115-119," Manila, Philippines: Asian Development Bank, 1999.
[3] D. Hongmin, L. Erda, L. Yue, R. Minjie, and Y. Qichang, "An estimation of methane emissions from agricultural activities in China," Ambio, vol. 25, no. 4, pp. 292-296, 1996.

[4] H. Dong, X. Tao, H. Xin, and Q. He, "Comparison of enteric methane emissions in China for different IPCC estimation methods and production schemes," Transactions of the American Society of Agricultural Engineers, vol. 47, no. 6, pp. 20512057, 2004.

[5] C. Liu, China Dairy Year Book 2008, China Agricultural Press, Beijing, China, 2008.

[6] J. Ma, L. Gan, X. Qian, H. Tan, and D. Xu, “The present status of milk industry in our country and the countermeasure of sustained growth," Journal of Agricultural Mechanization Research, vol. 1, pp. 50-52, 2006 (Chinese).

[7] Z. Gao, H. Yuan, W. Ma, X. Liu, and R. L. Desjardins, "Methane emissions from a dairy feedlot during the fall and winter seasons in Northern China," Environmental Pollution, vol. 159, no. 5, pp. 1183-1189, 2011.

[8] Food and Agriculture Organization of the United Nations, "Greenhouse gas emissions from the dairy sector: A life cycle assessment," p. 18 and p. 32, 2010.

[9] T. K. Flesch, J. D. Wilson, and E. Yee, "Backward-time Lagrangian stochastic dispersion models and their application to estimate gaseous emissions," Journal of Applied Meteorology, vol. 34, no. 6, pp. 1320-1332, 1995.

[10] T. K. Flesch, J. D. Wilson, L. A. Harper, B. P. Crenna, and R. R. Sharpe, "Deducing ground-to-air emissions from observed trace gas concentrations: a field trial," Journal of Applied Meteorology, vol. 43, no. 3, pp. 487-502, 2004.

[11] T. K. Flesch, J. D. Wilson, L. A. Harper, R. W. Todd, and N. A. Cole, "Determining ammonia emissions from a cattle feedlot with an inverse dispersion technique," Agricultural and Forest Meteorology, vol. 144, no. 1-2, pp. 139-155, 2007.

[12] L. A. Harper, T. K. Flesch, and J. D. Wilson, "Ammonia emissions from broiler production in the San Joaquin Valley," Poultry Science, vol. 89, no. 9, pp. 1802-1814, 2010.

[13] T. K. Flesch, R. L. Desjardins, and D. Worth, "Fugitive methane emissions from an agricultural biodigester," Biomass and Bioenergy, vol. 35, no. 9, pp. 3927-3935, 2011.

[14] R. P. Van Haarlem, R. L. Desjardins, Z. Gao, T. K. Flesch, and $\mathrm{X}$. Li, "Methane and ammonia emissions from a beef feedlot in western Canada for a twelve-day period in the fall," Canadian Journal of Animal Science, vol. 88, no. 4, pp. 641-649, 2008.

[15] Z. Gao, M. Mauder, R. L. Desjardins, T. K. Flesch, and R. P. van Haarlem, "Assessment of the backward Lagrangian Stochastic dispersion technique for continuous measurements of $\mathrm{CH}_{4}$ emissions," Agricultural and Forest Meteorology, vol. 149, no. 9, pp. 1516-1523, 2009.

[16] L. A. Harper, O. T. Denmead, J. R. Freney, and F. M. Byers, "Direct measurements of methane emissions from grazing and feedlot cattle," Journal of Animal Science, vol. 77, no. 6, pp. 1392-1401, 1999.

[17] R. Kinsman, F. D. Sauer, H. A. Jackson, and M. S. Wolynetz, "Methane and carbon dioxide emissions from dairy cows in full lactation monitored over a six-month period," Journal of Dairy Science, vol. 78, no. 12, pp. 2760-2766, 1995.

[18] Y. L. P. Le Du, R. D. Baker, and J. M. Barker, "Milk-fed calves. 2. The effect of length of milk feeding period and milk intake upon herbage intake and performance of grazing calves," Journal of Agricultural Science, vol. 87, pp. 197-204, 1976.

[19] K. H. Ominski, D. A. Boadi, K. M. Wittenberg, D. L. Fulawka, and J. A. Basarab, "Estimates of enteric methane emissions from cattle in Canada using the IPCC Tier-2 methodology," 
Canadian Journal of Animal Science, vol. 87, no. 3, pp. 459467, 2007.

[20] S. Husted, "Seasonal variation in methane emission from stored slurry and solid manures," Journal of Environmental Quality, vol. 23, no. 3, pp. 585-592, 1994.

[21] IPCC, "Emissions from livestock and manure management," in IPCC Guidelines for National Greenhouse Gas Inventories, chapter 10, 2006.

[22] A. B. Leytem, R. S. Dungan, D. L. Bjorneberg, and A. C. Koehn, "Emissions of ammonia, methane, carbon dioxide, and nitrous oxide from dairy cattle housing and manure management systems," Journal of Environmental Quality, vol. 40, no. 5, pp. 1383-1394, 2011.

[23] B. Amon, T. T. Amon, J. Boxberger, and C. Alt, "Emissions of $\mathrm{NH}_{3}, \mathrm{~N}_{2} \mathrm{O}$ and $\mathrm{CH}_{4}$ from dairy cows housed in a farmyard manure tying stall (housing, manure storage, manure spreading)," Nutrient Cycling in Agroecosystems, vol. 60, no. 1-3, pp. 103-113, 2001.

[24] L. A. Harper, T. K. Flesch, J. M. Powell, W. K. Coblentz, W. E. Jokela, and N. P. Martin, "Ammonia emissions from dairy production in Wisconsin," Journal of Dairy Science, vol. 92, no. 5, pp. 2326-2337, 2009.

[25] S. M. McGinn, T. K. Flesch, L. A. Harper, and K. A. Beauchemin, "An approach for measuring methane emissions from whole farms," Journal of Environmental Quality, vol. 35, no. 1, pp. 14-20, 2006.

[26] J. Laubach and F. M. Kelliher, "Methane emissions from dairy cows: comparing open-path laser measurements to profilebased techniques," Agricultural and Forest Meteorology, vol. 135, no. 1-4, pp. 340-345, 2005.

[27] C. Grainger, T. Clarke, S. M. McGinn et al., "Methane emissions from dairy cows measured using the sulfur hexafluoride (SF6) tracer and chamber techniques," Journal of Dairy Science, vol. 90, no. 6, pp. 2755-2766, 2007.

[28] E. Kebreab, K. Clark, C. Wagner-Riddle, and J. France, "Methane and nitrous oxide emissions from Canadian animal agriculture: a review," Canadian Journal of Animal Science, vol. 86, no. 2, pp. 135-158, 2006.

[29] K. A. Beauchemin and S. M. McGinn, "Methane emissions from feedlot cattle fed barley or corn diets," Journal of Animal Science, vol. 83, no. 3, pp. 653-661, 2005.

[30] X. P. C. Vergé, J. A. Dyer, R. L. Desjardins, and D. Worth, "Greenhouse gas emissions from the Canadian dairy industry in 2001," Agricultural Systems, vol. 94, no. 3, pp. 683-693, 2007.

[31] F. D. Sauer, V. Fellner, R. Kinsman et al., "Methane output and lactation response in holstein cattle with monensin or unsaturated fat added to the diet," Journal of Animal Science, vol. 76, no. 3, pp. 906-914, 1998.

[32] K. R. Lassey, "Livestock methane emission: from the individual grazing animal through national inventories to the global methane cycle," Agricultural and Forest Meteorology, vol. 142, no. 2-4, pp. 120-132, 2007.

[33] J. Li, Modern Dairy Cattle Production, China Agricultural University Press, Beijing, China, 2007.

[34] J. Wang, Modern Dairy Breeding, China Agriculture Press, Beijing, China, 2006.

[35] K. Johnson, M. Huyler, H. Westberg, B. Lamb, and P. Zimmerman, "Measurement of methane emissions from ruminant livestock using a SF6 tracer technique," Environmental Science and Technology, vol. 28, no. 2, pp. 359-362, 1994.

[36] D. A. Boadi and K. M. Wittenberg, "Methane production from dairy and beef heifers fed forages differing in nutrient density using the sulphur hexafluoride (SF6) tracer gas technique,"
Canadian Journal of Animal Science, vol. 82, no. 2, pp. 201206, 2002.

[37] T. A. McAllister, E. K. Okine, G. W. Mathison, and K. J. Cheng, "Dietary, environmental and microbiological aspects of methane production in ruminants," Canadian Journal of Animal Science, vol. 76, no. 2, pp. 231-243, 1996.

[38] M. A. Kujawa, Energy partitioning in steers fed cottonseed hulls and beet pulp, Ph.D Dissertation, Colorado State University, Fort Collins, Colo, USA, 1994. 

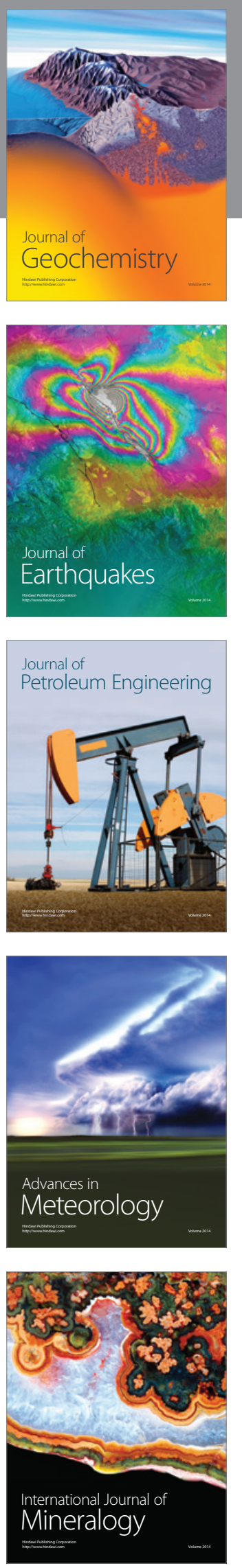
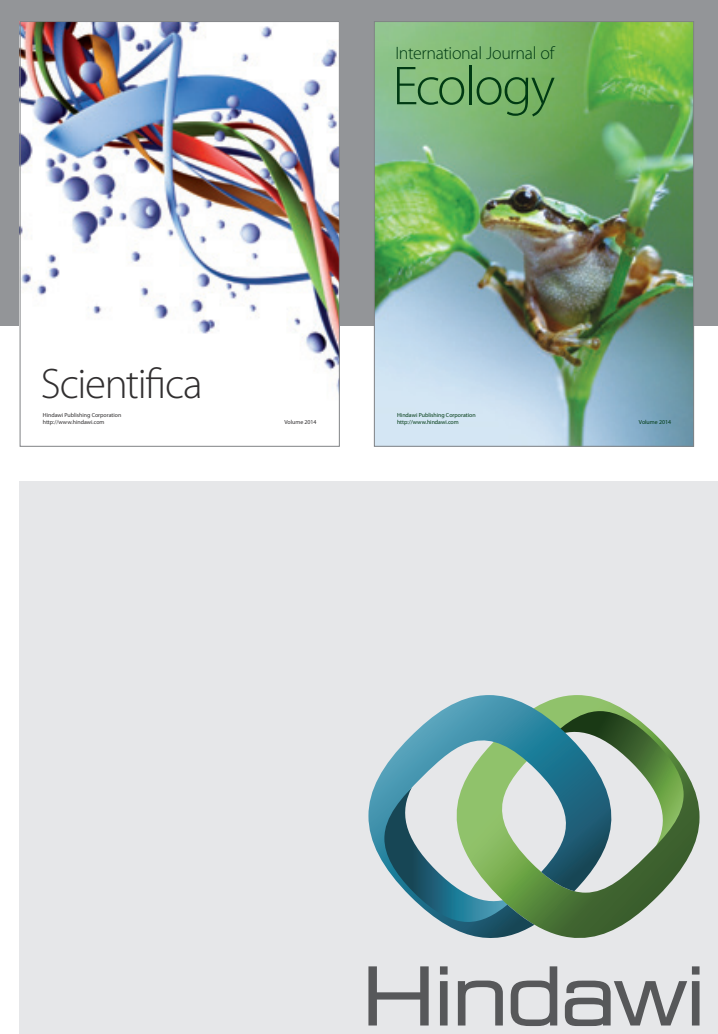

Submit your manuscripts at http://www.hindawi.com
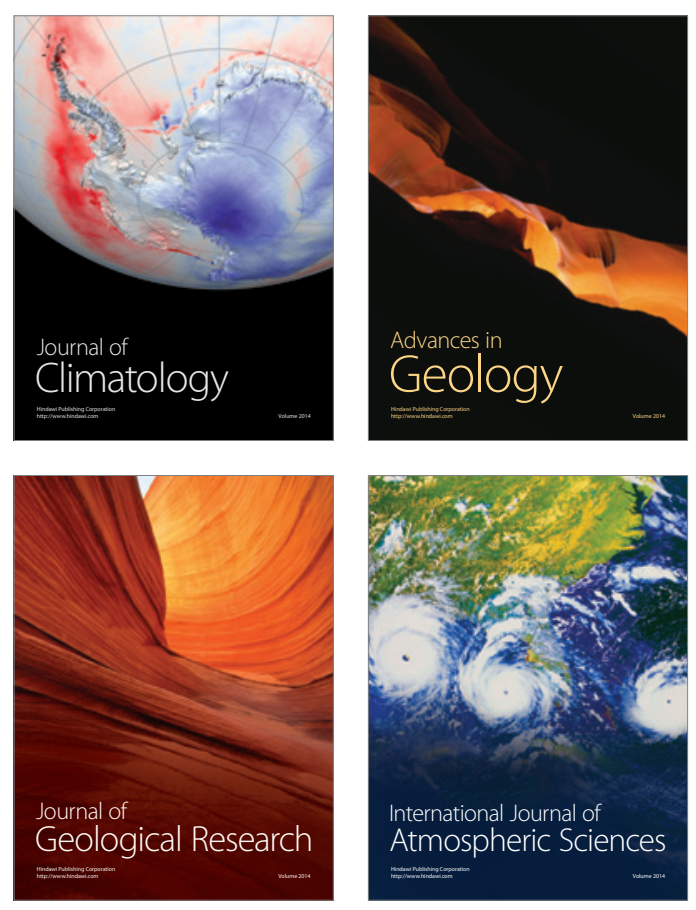
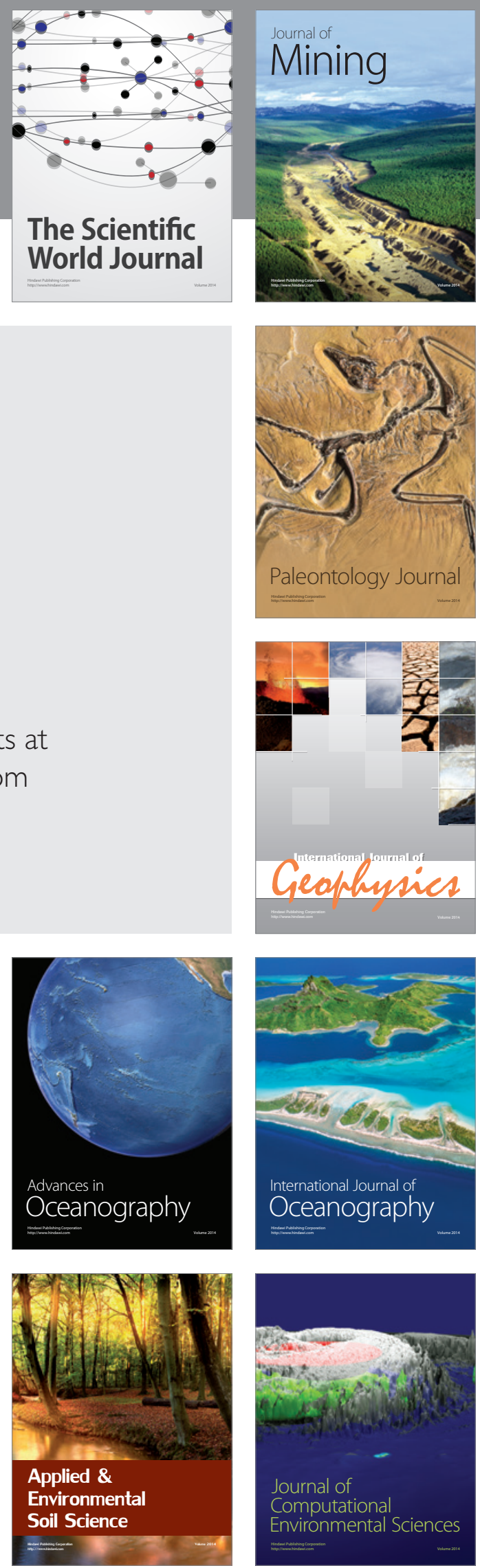